\title{
From Mate Retention to Murder: Evolutionary Psychological Perspectives on Men's Partner-Directed Violence
}

\author{
Farnaz Kaighobadi and Todd K. Shackelford \\ Florida Atlantic University
}

\author{
Aaron T. Goetz \\ California State University, Fullerton
}

\begin{abstract}
In response to the tragically high incidence and negative consequences of female-directed violence in intimate relationships, a large literature has been dedicated to the investigation of the proximate and the ultimate or evolutionary predictors of men's partner-directed violence. Evolutionary psychology offers a framework for investigating the design of evolved information-processing mechanisms that motivate costly behaviors such as men's partner-directed violence. We review several forms of men's partner-directed violence, including insults, sexual coercion, physical violence, and homicide, from an evolutionary psychological perspective and with a particular focus on the adaptive problem of paternity uncertainty. The problem of paternity uncertainty is hypothesized to have selected for the emotion of male sexual jealousy, which in turn motivates men's nonviolent and violent mate retention behaviors. We review empirical evidence for the relationships among paternity uncertainty, male sexual jealousy, and men's partner-directed violence. We propose that a comprehensive understanding of men's partner-directed violence will be achieved only by careful consideration of both proximate and ultimate causes.
\end{abstract}

Keywords: intimate partner violence, paternity uncertainty, male sexual jealousy, evolutionary psychology

According to the U.S. Department of Justice, in $200120 \%$ of reported incidents of nonfatal violence against women age 12 or older were perpetrated by an intimate partner (Bureau of Justice Statistics, 2003). This amounts to nearly 600,000 reported incidents of nonfatal violence against women by an intimate partner in just a single year in the United States (Bureau of Justice Statistics, 2003). Partly in response to the tragically high incidence of female-directed violence in intimate relationships and the devastating negative physical and psychological consequences of these behaviors, a large literature has been dedicated to investigation of risk factors and predictors associated with men's violence against intimate partners. Previous research has identified several proximate predictors of men's partner-directed violence, such as family history of aggression (Busby, Holman, \& Walker, 2008; Riggs \& O'Leary, 1996) and cultural influences (e.g., Archer, 2006a; Gage \& Hutchinson, 2006), as well as ultimate or evolutionary predictors of such costly behaviors, notably male sexual jealousy as a solution to the adaptive problem of paternity uncertainty (e.g., Goetz, Shackelford, Romero, Kaighobadi, \& Miner, 2008; Shackelford, Goetz, Buss, Euler, \& Hoier, 2005).

Increasingly over the past several decades, social scientists have recognized the value of an evolutionary perspective for guiding their research (Archer, 2006b; Cory, 1999; also see Dunbar, 2007). Evolutionary psychological theories have been applied successfully to the investigation of diverse human behaviors, including altruism and cooperation (Kruger, 2003; Stewart-Williams, 2008),

Farnaz Kaighobadi and Todd K. Shackelford, Department of Psychology, Florida Atlantic University; Aaron T. Goetz, Department of Psychology, California State University, Fullerton.

Correspondence concerning this article should be addressed to Farnaz Kaighobadi, Department of Psychology, Florida Atlantic University, 2912 College Avenue, Davie, FL 33314. E-mail: fkaighob@fau.edu conflict and violence (Archer, 2006b; Daly \& Wilson, 1988; Wilson \& Daly, 1998), decision making (Cosmides \& Tooby, 1992; Gigerenzer, 2008), interpersonal relationships (Ackerman \& Kenrick, 2008), and mating (Buss, 2000; Shackelford, Schmitt, \& Buss, 2005). Evolutionary psychology is concerned with identifying and describing the design and function of psychological adaptations that evolved to solve the specific problems our ancestors faced recurrently over human evolutionary history. These evolved mechanisms are information-processing devices that motivate behavior in response to particular environmental inputs. An evolutionary psychological perspective can guide research on intimate partner violence, notably research on the evolved mechanisms that motivate these behaviors.

Our goal in this article is to review briefly different forms of men's partner-directed violence, including insults, sexual coercion, physical violence, and homicide from an evolutionary psychological perspective and with a particular focus on the adaptive problem of paternity uncertainty.

\section{Paternity Uncertainty and Male Sexual Jealousy}

Over human evolutionary history, men and women have faced the adaptive problems of maintaining relationships and retaining intimate partners. Jealousy is an emotion that motivates behaviors that deter mate-poaching rivals and prevent partner infidelity or outright desertion from the relationship (Buss, Larsen, Westen, \& Semmelroth, 1992; Daly, Wilson, \& Weghorst, 1982; Symons, 1979). Men and women do not differ in the frequency or intensity with which they experience jealousy (Shackelford, LeBlanc, \& Drass, 2000). However, men and women respond differently to two different types of partner infidelity, emotional infidelity and sexual infidelity. Men are more distressed about a partner's sexual infidelity than about her emotional infidelity, whereas the opposite pattern is found for women. This sex difference has been docu- 
mented in more than a dozen empirical studies using various methods, including forced-choice self-report assessments (Buss et al., 1999), physiological assessments (Buss et al., 1992), experimental methods (Schützwohl, 2005, 2008; Thomson, Patel, Platek, \& Shackelford, 2007), and archival and cross-cultural data (e.g., Betzig, 1989).

The sex difference in the experience of jealousy may be attributable to sex-specific adaptive problems humans faced over their evolutionary history (Buss, 2000; Symons, 1979). It has been hypothesized that ancestral women faced the recurrent problems of paternal investment and acquisition and retention of resources with which to raise offspring. A partner's emotional infidelity might have predicted his current or future investment of resources in another woman and another woman's children. Ancestral men, in contrast, faced the adaptive problem of paternity uncertainty. Female sexual infidelity and subsequent cuckoldry - a man's unwitting investment in offspring to whom he is not genetically related-carried substantial reproductive costs for ancestral men. The reproductive costs of cuckoldry, including the loss of time, energy, resources, and alternative mating opportunities, are potentially so great that men have evolved to be sensitive to and to experience more distress about a partner's sexual infidelity. Men may also have evolved mechanisms that assess the risk of partner sexual infidelity and mechanisms that motivate the performance of anticuckoldry tactics. Goetz (2007) hypothesized that to assess the likelihood or risk of partner sexual infidelity, these informationprocessing mechanisms may use cues such as greater time spent apart from the partner, the presence of potential rivals, and a partner's attractiveness, or her "mate value" as a short-term partner or long-term partner (Goetz \& Shackelford, 2006; Peters, Shackelford, \& Buss, 2002; Schmitt \& Buss, 2001; Shackelford \& Buss, 1997; Shackelford, Goetz, McKibbin, \& Starratt, 2007; Trivers, 1972; Wilson \& Daly, 1993). The behavioral output of male sexual jealousy varies from subtle nonviolent mate retention behaviors to outright physical violence.

\section{Male Sexual Jealousy and Mate Retention Behaviors}

One class of behavioral output of sexual jealousy is men's mate retention behaviors, which function to prevent a partner's infidelity or outright relationship defection or to thwart rivals' attempts to encroach on the relationship. Buss (1988b) developed a taxonomy of mate retention behaviors organized into five categories: acts of direct guarding function to keep a partner under surveillance; acts of intersexual negative inducement include threats to punish a partner's infidelity; acts of positive inducement include expressions of affection and care; acts of public signals of possession include acts intended to signal possession of a partner to potential rivals; and acts of intrasexual negative inducement include acts intended to threaten potential rivals and thereby deter them from encroaching on the relationship. As the risk of female infidelity increases, men perform more frequent mate retention behaviors. For example, Buss and Shackelford (1997) found that men mated to younger, more attractive partners (cues to reproductive value or expected future reproduction) and men who perceive greater probability of partner infidelity guard their partners more intensely. Also, men perform more frequent mate retention behaviors when they are mated to women who possess qualities that predict their infidelity, including personality characteristics such as surgency and openness to experience (Goetz et al., 2005), and when their partner is near ovulation - a time when a female infidelity would be most costly for the in-pair male (Gangestad, Thornhill, \& Garver, 2002). Because time spent physically apart from a partner increases the risk of a partner's infidelity, men who have spent a greater proportion of time apart from their partners also report engaging in more frequent mate retention behaviors (Starratt, Shackelford, Goetz, \& McKibbin, 2007). In addition, McKibbin et al. (2007) identified positive relationships between men's accusations of their partner's infidelity and the frequency with which they performed several categories of mate retention.

A more physically damaging output of male sexual jealousy is partner-directed violence. Male sexual jealousy is one of the most frequently cited causes of men's partner-directed violence, both physical and sexual (e.g., Buss, 2000; Daly \& Wilson, 1988; Daly et al., 1982; Dobash \& Dobash, 1979; Dutton, 1998; Frieze, 1983; Gage \& Hutchinson, 2006; Russell, 1982; Walker, 1979). The frequency with which men perform nonviolent mate retention behaviors predicts the frequency with which they inflict physical violence against their partners because both classes of behavior are hypothesized to be outputs of sexual jealousy. In three studies, Shackelford, Goetz, et al. (2005) investigated the relationship between men's nonviolent mate retention behaviors and men's partner-directed violence. On the basis of men's self-reports, women's partner reports, and cross-spouse reports, men's use of emotional manipulation as a mate retention tactic-marked by the performance of acts such as "I told my partner I would die if she ever left me"- predicted female-directed violence. Men's monopolization of their partner's time and men's sexual inducements also predicted men's physical violence against their partners. Because suspicions of partner infidelity explain the variance in men's mate retention behaviors and because men's mate retention behaviors predict men's partner-directed violence, Kaighobadi, Starratt, Shackelford, and Popp (2008) hypothesized that men's suspicions of their partner's infidelity may be linked directly to partnerdirected violence. In two studies using men's self-reports and women's partner reports, Kaighobadi et al. (2008) found that men's accusations of their partner's infidelity explain a small but significant variance in men's partner-directed violence. Moreover, this relationship is mediated by nonviolent mate retention behaviors. Kaighobadi et al. hypothesized that men perform nonviolent and violent mate retention behaviors in a temporal hierarchical fashion. Less severe, less costly behaviors might be deployed first, followed by more severe behaviors such that the hierarchy of events leading to female-directed violence is initiated with men's suspicions of partner infidelity followed by nonviolent mate retention behaviors and ending in acts of physical violence.

Puente and Cohen (2003) conducted a series of studies investigating third-party observer perceptions of male sexual jealousy and female-directed violence. They found that observers were more accepting of violent behavior in scenarios in which intimate partner violence followed the male aggressor's experience of sexual jealousy. When the male aggressor was described as sexually jealous, observers were less inclined to convict him of a crime and assumed that the female victim would also be less inclined to file charges against her partner. Puente and Cohen also found that jealous abusers were perceived by observers as more romantically in love with their partner than nonjealous abusers. It therefore appears that people readily and intuitively render judgments and 
reach conclusions on the basis of an expected relationship between men's jealousy and men's partner-directed violence. A third-party observer's ready inference of a relationship between male sexual jealousy and men's partner-directed violence is consistent with the operation of an implicit mechanism underlying these judgments.

\section{Forced In-Pair Copulation in Nonhuman Animals}

Instances of forced in-pair copulation have been documented in avian species that form long-term pair bonds (Bailey, Seymour, \& Stewart, 1978; Barash, 1977; Birkhead, Hunter, \& Pellatt, 1989; Cheng, Burns, \& McKinney, 1983; Goodwin, 1955; McKinney, Cheng, \& Bruggers, 1984; McKinney \& Stolen, 1982). Forced in-pair copulation is hypothesized to be a form of postcopulatory male-male competition, that is, a sperm competition tactic (Barash, 1977; Cheng et al., 1983; Lalumière, Harris, Quinsey, \& Rice, 2005; McKinney et al., 1984), because it often follows a female partner's extrapair copulation or intrusions by rival males (e.g., Bailey et al., 1978; Barash, 1977; Birkhead et al., 1989; Cheng et al., 1983; Goodwin, 1955; McKinney, Derrickson, \& Mineau, 1983; McKinney \& Stolen, 1982; Seymour \& Titman, 1979; Valera, Hoi, \& Kristin, 2003). Sperm competition occurs when a female copulates with and is inseminated by more than one male in a sufficiently brief period of time (Parker, 1970). Thus, by forcing the female to copulate shortly after the increased risk of insemination by a rival, males place their sperm in competition with any sperm deposited into their partner by a rival male (Birkhead et al., 1989; Cheng et al., 1983).

Observations of sperm competition in nonhuman species offer a framework with which to consider similar adaptations in humans, who also form long-term socially (but not genetically) monogamous pair bonds. Recent evidence has suggested that sperm competition has been a recurrent feature of human evolutionary history and that men have physiological and psychological mechanisms that may have evolved to solve related adaptive problems (Baker \& Bellis, 1993; Gallup et al., 2003; Goetz et al., 2005; Kilgallon \& Simmons, 2005; Pound, 2002; Shackelford \& Goetz, 2007; Shackelford \& Pound, 2006; Shackelford et al., 2002; Shackelford, Pound, \& Goetz, 2005; Smith, 1984; Wyckoff, Wang, \& Wu, 2000). For example, with increased risk of a partner's infidelity, men display copulatory urgency, perform more semen-displacing behaviors at next copulation, and adjust their ejaculates to include more sperm (Baker \& Bellis, 1993; Goetz et al., 2005; Shackelford et al., 2007). Men's perception of their partner's physical and sexual attractiveness - a proxy for risk of sperm competition-also predicts the frequency of in-pair copulations. Men engage in more frequent in-pair copulations when they perceive their partner to be more physically and sexually attractive (Kaighobadi \& Shackelford, 2008).

\section{Risk of Sperm Competition and Sexual Coercion}

Sexual coercion or rape of an intimate partner is also a hypothesized manifestation of male sexual jealousy, which may be a response to perceived risk of sperm competition. Between $10 \%$ and $26 \%$ of women report being raped by their husband (Finkelhor \& Yllo, 1985; Hadi, 2000; Painter \& Farrington, 1999; Russell, 1982; Watts, Keough, Ndlovu, \& Kwaramba, 1998). In a sample of young adults in a committed sexual relationship, Goetz and Shack- elford (2006) found that $7.3 \%$ of men admitted to at least one incidence of raping their current partner and that $9.1 \%$ of women reported having experienced at least one incidence of rape by their current partner.

Many studies have investigated men's sexual coercion in an intimate relationship. Several hypotheses have been formulated to test the proximate or immediate predictors of men's sexual coercion of an intimate partner and also the ultimate or evolutionary predictors of men's sexual coercion of an intimate partner. Several scholars have argued that men's sexual coercion of their partner is motivated by a desire to dominate and control the partner (e.g., Basile, 1999; Bergen, 1996; Frieze, 1983; Gage \& Hutchinson, 2006; Gelles, 1977; Meyer, Vivian, \& O'Leary, 1998; Watts et al., 1998). For example, several studies have found that men who are physically abusive toward their partners are also more likely to be sexually coercive toward their partners than are men who are not physically abusive (Apt \& Hurlbert, 1993; DeMaris, 1997; Donnelly, 1993; Finkelhor \& Yllo, 1985; Koziol-McLain, Coates, \& Lowenstein, 2001; Shackelford \& Goetz, 2004). Shackelford and Goetz (2004) also found a positive relationship between men's nonviolent controlling behavior and men's sexual coercion of their partners. Gage and Hutchinson (2006) found that women's experience of sexual coercion by their partner is predicted by their partner's jealousy and nonviolent controlling behavior but is not predicted by differences in social power between the partners. To address these apparently conflicting results regarding sexual coercion of intimate partners and men's motivation to gain or exert control over their partners, Goetz and Shackelford (2009) investigated several relevant predictors of sexual coercion, securing men's self-reports and women's partner reports. They found that men's sexual coercion of their partners is predicted by both suspicions of female infidelity and by men's controlling behavior, suggesting that both classes of variables contribute to an explanation for men's sexual coercion in intimate relationships.

The desire to dominate and control a partner may explain some portion of the individual differences in men's sexually coercive behaviors, but the proponents of the domination and control hypothesis have argued that men as a group are motivated to exert "patriarchal terrorism" or "patriarchal power" over all women through sexual coercion of their own partners (e.g., Brownmiller, 1975; Johnson, 1995). We are unaware of research that has empirically tested these hypotheses. We note, however, that hypotheses that propose coordinated male-male cooperation to dominate and control women are not consistent with substantial theoretical and empirical work that has highlighted the frequency and intensity of male-male competition (rather than cooperation) for attracting women as intimate partners (Bleske \& Shackelford, 2001; Buss, 1988a; Schmitt \& Buss, 1996; Trivers, 1972).

Sexual coercion is also hypothesized to function as an anticuckoldry tactic (Gallup \& Burch, 2006; Lalumière et al., 2005; Thornhill \& Thornhill, 1992; Wilson \& Daly, 1992; see also Goetz \& Shackelford, 2006). It has been hypothesized that by forcing their partners to have sex, men who are suspicious of their partner's infidelity introduce their own sperm into their partner's reproductive tract and thereby decrease the risk of cuckoldry. This sperm competition hypothesis for partner rape has been applied to nonhumans (notably, several avian species) to account for observations of partner rape immediately after female extrapair copula- 
tions (e.g., Barash, 1977; Cheng et al., 1983; McKinney et al., 1984). Rape of an intimate partner in humans also often follows accusations of female sexual infidelity (e.g., Finkelhor \& Yllo, 1985; Russell, 1982).

Gallup and Burch (2006) proposed the intrapair copulation proclivity model of female infidelity to predict and explain variance in the likelihood of men's sexual coercion of their partner after female sexual infidelity. Gallup and Burch argued that, on one hand, men have a propensity to engage in immediate copulation with their partner when they perceive a high risk of recent female infidelity. On the other hand, women may attempt to avoid copulating with their regular partner immediately after an extrapair copulation. Extrapair copulations may function to secure "good" genes from men other than the woman's regular partner, and copulating immediately with her regular partner may cause displacement of the extrapair sperm or otherwise interfere with the ability of the extrapair sperm to fertilize the woman's egg(s). Thus, Gallup and Burch argued that men's copulatory urgency following detection of partner infidelity, and women's concurrent copulatory reluctance, may increase the risk of men's sexual coercion of their partner.

In two studies securing data from men's self-reports and women's partner reports, Goetz and Shackelford (2006) found that men's sexual coercion correlated positively with women's past and future likelihood of engaging in sexual infidelity. They also found that men who perform more mate retention behaviors are also more likely to perform sexually coercive behaviors against their partners, as reported by men and by their partners. Several studies have documented a positive relationship between men's sexual jealousy and men's sexual coercion of their partners. For example, Frieze (1983) and Gage and Hutchinson (2006) found that men who sexually coerced their wives were more sexually jealous than men who did not. Previous research has found a direct positive relationship between men's suspicions and accusations of partner infidelity and men's sexual coercion of their partners (Starratt, Goetz, Shackelford, \& Stewart-Williams, 2008).

According to Goetz and Shackelford (2009), the domination and control hypothesis and the sperm competition hypothesis reflect different levels of analysis. The domination and control hypothesis offers a proximate explanation of partner sexual coercion, including social or cultural causes of behavior. The sperm competition hypothesis offers an ultimate explanation of partner sexual coercion and addresses how adaptations that produce such costly behaviors could have evolved. Goetz and Shackelford did not argue that all sexually coercive behaviors are produced by evolved mechanisms that motivate anticuckoldry behaviors. Instead, they attempted to explain the increased likelihood of sexual coercion in the context of risk of female infidelity. It may be that some instances of sexual coercion are the result of, for example, an antisocial man's motivation to control, dominate, or humiliate his partner (see Goetz, Shackelford, Starratt, \& McKibbin, 2008). Future research can investigate the interaction of individual differences in men's perpetration of sexual coercion and evolutionarily relevant contexts such as the risk of female infidelity and sperm competition to predict men's sexual coercion and rape of their partners.

\section{Intimate Partner Homicide}

According to the U.S. Department of Justice (Bureau of Justice Statistics, 2007), between 1976 and 2005, 30\% of female homicide ("femicide") victims were killed by an intimate partner, making it the largest class of victim-offender relationship. In sharp contrast, just $5 \%$ of all male homicide victims were killed by an intimate partner. In most categories of intimate partner homicide, men far outnumber women as the perpetrator and women far outnumber men as the victim (Daly \& Wilson, 1988; Dobash \& Dobash, 1979). Many studies have been dedicated to the investigation of the predictors and risk factors associated with female partner homicide. Campbell et al. (2003), for example, used a multisite case control study to investigate the risk factors associated with intimate partner femicide. The results indicated that male partner's unemployment was the most significant sociodemographic risk factor for intimate partner femicide. They also found that the risk of intimate partner femicide increased by five times when the victim left the abusive partner for another man or when sexual jealousy was triggered (Campbell et al., 2003). Additional empirical evidence has suggested increased risk of intimate partner femicide in response to the victim's attempt to leave the relationship (e.g., McFarlane et al., 1999; Nicolaidis et al., 2003; U.S. Department of Justice, 1998). Campbell et al. also documented that having a child from the victim's previous partner living in the home doubled the risk of intimate partner femicide. This result parallels Burch and Gallup's (2000) report of increased frequency and severity of female-directed partner abuse when children unrelated to the man are living in the household.

Nicolaidis et al. (2003) conducted 30 in-depth interviews with women who survived an attempted homicide by their intimate partner. They found that 20 women $(67 \%)$ had a history of prior violence with the partner. Twenty-five women (83\%) explicitly mentioned their partner's prior stalking, sexual jealousy, accusations of infidelity, social isolation, physical limitations, or threats of violence against the woman. In $22(73 \%)$ of the cases, the male partner attempted femicide when the woman threatened to leave the relationship.

Several hypotheses have been advanced to explain the occurrence and frequency of intimate partner homicide, and we review briefly here two of the leading hypotheses. According to one hypothesis, the "killing-as-a-by-product" hypothesis, because killing a partner carries substantial and severe costs that might not have consistently produced sufficient benefits over human evolutionary history, it is unlikely to be the product of specialized adaptations. The costs associated with killing a partner include the risk of retaliation by the victim's kin and the local community; the loss of time, energy, and resources a man invested in maintaining the relationship; reputational damage; and the loss of maternal investment in any shared offspring. Thus, partner killing might be a by-product of other male psychological adaptations, including adaptations specialized to motivate nonlethal punishment of a partner's suspected or actual infidelity and to control her sexual interactions (Daly \& Wilson, 1988; Wilson \& Daly, 1998; Wilson, Daly, \& Daniele, 1995). Wilson and Daly (1998) argued that men's "sexual proprietariness" is a key cause of $80 \%$ of spousal homicides. They defined sexual proprietariness as a combination of sexual jealousy and men's "presumptions of entitlement" and motivation to control their partner's sexual behavior. 
Proponents of a second hypothesis for intimate partner homicide (Buss \& Duntley, 1998, 2003) have argued that the by-product hypothesis cannot explain the large incidence of apparently premeditated partner homicides. Premeditated homicides include hiring someone to kill the partner, aiming at and shooting a partner, or deliberately poisoning a partner. Buss and Duntley $(1998,2003)$ argued that partner killing by men might be the function of a specialized adaptation in the context of suspected or actual female infidelity (and, as a consequence, paternity uncertainty). This evolved homicide module hypothesis does not imply that discovery of female sexual infidelity will always or even frequently lead to partner killing by men but instead that the relevant evolved mechanisms are likely to be activated with suspicions of female partner infidelity and may very occasionally result in partner killing (see Buss, 2005). The results from previous studies may provide evidence for the evolved homicide module hypothesis, in that men most frequently kill or attempt to kill their partner when the partner threatens to leave the relationship (Campbell et al., 2003; McFarlane et al., 1999; Nicolaidis et al., 2003; U.S. Department of Justice, 1998, also see Garcia, Soria, \& Hurwitz, 2007, for a review).

\section{Individual Differences in Intimate Partner Violence}

Previous research has identified links between men's partnerdirected violence and men's personality traits, including antisocial tendencies (Dutton, 1994; Dutton \& Starzomski, 1993), selfcenteredness (Dean \& Malamuth, 1997), lack of emotional regulation (McNulty \& Hellmuth, 2008), and impulsivity (Stuart \& Holtzworth-Munroe, 2005; also see White, McMullin, Swartout, Sechrist, \& Gollehon, 2008, for a review). Hellmuth and McNulty (2008) noted that most previous research addressing individual differences in men's perpetration of intimate partner violence has investigated personality disorders as predictors of partner-directed violence and less research has addressed variation in normal personality traits such as those assessed by the five factor personality model. Hellmuth and McNulty (2008) documented that husbands' and wives' emotional stability interact with levels of chronic stress to influence the frequency with which violence is inflicted against spouses. Busby et al. (2008) also found a relationship between partner reports of neuroticism and violence in intimate relationships.

To address this empirical gap in the literature, Kaighobadi, Shackelford, Popp, and Moyer (2009) investigated the relationships between men's personality traits as assessed by the five factor personality model and men's partner-directed violence. They hypothesized that men's personality traits may interact with situational contexts that trigger male sexual jealousy to predict intimate partner violence. The results indicated that men's emotional stability, agreeableness, and conscientiousness predict men's partner-directed violence. Men who score low on these personality traits are more likely to perpetrate violence against their partners. More important, however, the results indicated that men's suspicions of their partner's infidelity moderate the relationship between men's personality traits and men's partner-directed violence. In other words, personality affects partner-directed violence differently depending on men's perceptions of their partner's risk of infidelity (Kaighobadi et al., 2009).
Other studies have identified additional sources of individual differences in partner-directed violence, including family history of aggression (Busby et al., 2008), childhood sexual and physical abuse (Prentky, Knight, \& Sims-Knight, 1989), alcohol and drug use (Klostermann \& Fals-Stewart, 2006; Stuart \& HoltzworthMunroe, 2005), and problem-solving skills (Riggs \& O'Leary, 1989).

\section{Conclusion}

Evolutionary psychologists are interested in identifying the ultimate (or distal) explanations for a trait or behavior. Intimate partner violence and homicide are costly behaviors for both the victim and the perpetrator. It is useful to consider an evolutionary perspective to investigate the design features and evolved function of the psychological mechanisms that motivate these behaviors. An evolutionary psychological perspective can guide identification of the contexts that trigger the relevant information-processing mechanisms and motivate the subsequent behaviors. Many instances of intimate partner violence and homicide co-occur with and may be triggered by men's suspicions or knowledge of their female partner's sexual infidelity. However, this does not mean that individual differences do not exist in men's perpetration of violence against intimate partners.

Previous research has identified several proximate correlates of female-directed violence, such as a family history of aggression (Busby, Holman, \& Walker, 2008; Riggs \& O'Leary, 1996) and acceptance of local cultural norms (e.g., Archer, 2006a; Gage \& Hutchinson, 2006). Previous research has also investigated men's personality traits as predictors of men's partner-directed violence (see White, Darcy, Swartout, Sechrist, \& Gollehon, 2008, for review).

Situational factors including the characteristics of the perpetrator and those of the victim and the circumstances in which the violence occurs have also been considered in research investigating intimate partner violence and homicide (see Wilkinson \& Hamerschlag, 2005). For example, the perpetrator's age and the victim's age (Shackelford, Buss, \& Peters, 2000), the perpetrator's mental health (Dutton \& Kerry, 1999), and the availability of weapons (Paulozzi, Saltzman, Thompson, \& Holmgreen, 2001) have been investigated as risk factors associated with intimate partner violence.

In conclusion, it is important to investigate both the proximate and the ultimate causes of intimate partner violence. The relevant evolved psychological mechanisms interact with stable dispositions and situational factors to produce manifest behavior. Future research might benefit by taking an evolutionary perspective to build models of intimate partner violence that include both stable dispositions such as personality traits and environmental factors such as a family history of aggression. To achieve a fuller understanding of intimate partner violence and homicide, researchers must include a careful consideration of the evolved psychological mechanisms that motivate these costly behaviors.

\section{References}

Ackerman, J. M., \& Kenrick, D. T. (2008). The costs of benefits: Helprefusals highlight key trade-offs of social life. Personality and Social Psychology Review, 12, 118-140. 
Apt, C., \& Hurlbert, D. F. (1993). The sexuality of women in physically abusive marriages: Comparative study. Journal of Family Violence, 8, $57-69$.

Archer, J. (2006a). Cross-cultural differences in physical aggression between partners: A social-role analysis. Personality and Social Psychology Review, 10, 133-153.

Archer, J. (2006b). Testosterone and human aggression: An evaluation of the challenge hypothesis. Neuroscience \& Biobehavioral Reviews, 30, 319-345.

Bailey, R. O., Seymour, N. R., \& Stewart, G. R. (1978). Rape behavior in blue-winged teal. Auk, 95, 188-190.

Baker, R. R., \& Bellis, M. A. (1993). Human sperm competition: Ejaculate adjustment by males and the function of masturbation. Animal Behaviour, 46, 861-885.

Barash, D. P. (1977). Sociobiology of rape in mallards (Anas platyrhynchos): Response of the mated male. Science, 197, 788-789.

Basile, K. C. (1999). Rape by acquiescence: The ways in which women "give in" in unwanted sex with their husbands. Violence Against Women, 5, 1036-1058.

Bergen, R. K. (1996). Wife rape: Understanding the response of survivors and service providers. Thousand Oaks, CA: Sage.

Betzig, L. (1989). Causes of conjugal dissolution: A cross-cultural study. Current Anthropology, 30, 654-676.

Birkhead, T. R., Hunter, F. M., \& Pellatt, J. E. (1989). Sperm competition in the zebra finch, Taeniopygia guttata. Animal Behaviour, 38, 935-950.

Bleske, A. L., \& Shackelford, T. K. (2001). Poaching, promiscuity, and deceit: Combating mating rivalry in same-sex friendships. Personal Relationships, 8, 407-424

Brownmiller, S. (1975). Against our will: Men, women, and rape. New York: Simon \& Schuster.

Burch, R. L., \& Gallup, G. G., Jr. (2000). Perceptions of paternal resemblance predict family violence. Human Behavior and Evolution, 21, $429-435$.

Bureau of Justice Statistics. (2003, February). Intimate partner violence, 1993-2001. Washington, DC: U.S. Department of Justice, Office of Justice Programs.

Bureau of Justice Statistics. (2007, December). Intimate partner violence: Victim characteristics, 1976-2005. Washington, DC: U.S. Department of Justice, Office of Justice Programs.

Busby, D. M., Holman, T. B., \& Walker, E. (2008). Pathways to relationship aggression between adult partners. Family Relations, 57, 72-83.

Buss, D. M. (1988a). The evolution of human intrasexual competition: Tactics of mate attraction. Journal of Personality and Social Psychology, 54, 616-628.

Buss, D. M. (1988b). From vigilance to violence: Tactics of mate retention in American undergraduates. Ethology and Sociobiology, 9, 291-317.

Buss, D. M. (2000). The dangerous passion. New York: Free Press.

Buss, D. M. (2005). The murderer next door. New York: Penguin Press.

Buss, D. M., \& Duntley, J. D. (1998, July). Evolved homicide modules. Paper presented at the Annual Meeting of the Human Behavior and Evolution Society, Davis, California.

Buss, D. M., \& Duntley, J. D. (2003). Homicide: An evolutionary perspective and implications for public policy. In N. Dress (Ed.), Violence and public policy (pp. 115-128). Westport, CT: Greenwood.

Buss, D. M., Larsen, R. J., Westen, D., \& Semmelroth, J. (1992). Sex differences in jealousy: Evolution, physiology and psychology. Psychological Science, 3, 251-255.

Buss, D. M., \& Shackelford, T. K. (1997). From vigilance to violence: Mate retention tactics in married couples. Journal of Personality and Social Psychology, 72, 346-361.

Buss, D. M., Shackelford, T. K., Kirkpatrick, L. A., Chloe, J., Hasegawa, M., Hasegawa, T., \& Bennett, K. (1999). Jealousy and beliefs about infidelity: Tests of competing hypotheses in the United States, Korea, and Japan. Personal Relationships, 6, 125-150.
Campbell, J. C., Webster, D., Koziol-McLain, J., Block, C., Campbell, D., Curry, M. A., . . \& \& Laughon, K. (2003). Risk factors for femicide in abusive relationships: Results from a multisite case control study. American Journal of Public Health, 93, 1089-1097.

Cheng, K. M., Burns, J. T., \& McKinney, F. (1983). Forced copulation in captive mallards: III. Sperm competition. Auk, 100, 302-310.

Cory, G. (1999). The reciprocal modular brain in economics and politics: Shaping the rational and moral basis of organization, exchange, and choice. New York: Plenum Press.

Cosmides, L., \& Tooby, J. (1992). Cognitive adaptations for social exchange. In J. H. Barkow, L. Cosmides, \& J. Tooby (Eds.), The adapted mind: Evolutionary psychology and the generation of culture (pp. 163 228). New York: Oxford University Press.

Daly, M., \& Wilson, M. (1988). Homicide. Hawthorne, NY: Aldine de Gruyter.

Daly, M., Wilson, M., \& Weghorst, J. (1982). Male sexual jealousy. Ethology and Sociobiology, 3, 11-27.

Dean, K. E., \& Malamuth, N. M. (1997). Characteristics of men who aggress sexually and of men who imagine aggressing: Risk and moderating variables. Journal of Personality and Social Psychology, 72, 449455.

DeMaris, A. (1997). Elevated sexual activity in violent marriages: Hypersexuality or sexual extortion? Journal of Sex Research, 34, 361-373.

Dobash, R. E., \& Dobash, R. P. (1979). Violence against wives. New York: Free Press.

Donnelly, D. A. (1993). Sexually inactive marriages. Journal of Sex Research, 30, 171-179.

Dunbar, R. I. M. (2007). Evolution and the social sciences. History of the Human Sciences, 20, 29-50.

Dutton, D. G. (1994). The origin and structure of the abusive personality. Journal of Personality Disorders, 8, 181-191.

Dutton, D. G. (1998). The abusive personality. New York: Guilford Press.

Dutton, D. G., \& Kerry, G. (1999). Modus operandi and personality disorder in incarcerated spousal killers. International Journal of Law and Psychiatry, 22, 287-299.

Dutton, D. G., \& Starzomski, A. J. (1993). Borderline personality in perpetrators of psychological and physical abuse. Violence and Victims, 8, 327-337.

Finkelhor, D., \& Yllo, K. (1985). License to rape: Sexual abuse of wives. New York: Holt, Rinehart, \& Winston.

Frieze, I. H. (1983). Investigating the causes and consequences of marital rape. Signs: Journal of Women in Culture and Society, 8, 532-553.

Gage, A. J., \& Hutchinson, P. L. (2006). Power, control, and intimate partner sexual violence in Haiti. Archives of Sexual Behavior, 35, 11-24.

Gallup, G. G., Jr., \& Burch, R. L. (2006). The semen displacement hypothesis: Semen hydraulics and the intra-pair copulation proclivity model of female infidelity. In S. M. Platek \& T. K. Shackelford (Eds.), Female infidelity and paternal uncertainty: Evolutionary perspectives on male anti-cuckoldry tactics (pp. 129-140). New York: Cambridge University Press.

Gallup, G. G., Jr., Burch, R. L., Zappieri, M. L., Parvez, R. A., Stockwell, M. L., \& Davis, J. A. (2003). The human penis as a semen displacement device. Evolution and Human Behavior, 24, 277-289.

Gangestad, S. W., Thornhill, R., \& Garver, C. E. (2002). Changes in women's sexual interests and their partner's mate-retention tactics across the menstrual cycle: Evidence for shifting conflicts of interest. Proceedings of the Royal Society of London, 269, 975-982.

Garcia, L., Soria, C., \& Hurwitz, E. L. (2007). Homicides and intimate partner violence: A literature review. Trauma, Violence, \& Abuse, 8, 370-383.

Gelles, R. (1977). Power, sex and violence: The case of marital rape. Family Coordinator, 26, 339-347.

Gigerenzer, G. (2008). Why heuristics work. Perspectives on Psychological Science, 3, 20-29. 
Goetz, A. T. (2007). Violence and abuse in families: The consequences of paternal uncertainty. In C. Salmon \& T. K. Shackelford (Eds.), Family relationships: An evolutionary perspective (pp. 259-274). New York: Oxford University Press.

Goetz, A. T., \& Shackelford, T. K. (2006). Sexual coercion and forced in-pair copulation as sperm competition tactics in humans. Human Nature, 17, 265-282.

Goetz, A. T., \& Shackelford, T. K. (2009). Sexual coercion in intimate relationships: A comparative analysis of the effects of women's infidelity and men's dominance and control. Archives of Sexual Behavior, 38, 226-234.

Goetz, A. T., Shackelford, T. K., Romero, G. A., Kaighobadi, F., \& Miner, E. J. (2008). Punishment, proprietariness, and paternity: Men's violence against women from an evolutionary perspective. Aggression and Violent Behavior, 13, 481-489.

Goetz, A. T., Shackelford, T. K., Starratt, V. G., \& McKibbin, W. F. (2008). Intimate partner violence. In J. D. Duntley \& T. K. Shackelford (Eds.), Evolutionary forensic psychology (pp. 65-78). New York: Oxford University Press.

Goetz, A. T., Shackelford, T. K., Weekes-Shackelford, V. A., Euler, H. A., Hoier, S., Schmitt, D. P., \& LaMunyon, C. W. (2005). Mate retention, semen displacement, and human sperm competition: A preliminary investigation of tactics to prevent and correct female infidelity. Personality and Individual Differences, 38, 749-763.

Goodwin, D. (1955). Some observations on the reproductive behavior of rooks. British Birds, 48, 97-107.

Hadi, A. (2000). Prevalence and correlates of the risk of marital sexual violence in Bangladesh. Journal of Interpersonal Violence, 15, 787805

Hellmuth, J. C., \& McNulty, J. K. (2008). Neuroticism, marital violence, and the moderating role of stress and behavioral skills. Journal of Personality and Social Psychology, 95, 166-180.

Johnson, M. P. (1995). Patriarchal terrorism and common couple violence: Two forms of violence against women. Journal of Marriage and the Family, 57, 283-294

Kaighobadi, F., \& Shackelford, T. K. (2008). Female attractiveness mediates the relationship between in-pair copulation frequency and men's mate retention behaviors. Personality and Individual Differences, 45, 293-295.

Kaighobadi, F., Shackelford, T. K., Popp, D., \& Moyer, R. (2009, May). Female infidelity risk moderates the relationship between men's personality and partner-directed violence. Paper presented at the 21 st annual conference of the Association for Psychological Science, San Francisco.

Kaighobadi, F., Starratt, V. G., Shackelford, T. K., \& Popp, D. (2008). Male mate retention mediates the relationship between female sexual infidelity and female-directed violence. Personality and Individual Differences, 44, 1422-1431.

Kilgallon, S. J., \& Simmons, L. W. (2005). Image content influences men's semen quality. Biology Letters, 1, 253-255.

Klostermann, K. C., \& Fals-Stewart, W. (2006). Intimate partner violence and alcohol use: Exploring the role of drinking in partner violence and its implications for intervention. Aggression and Violent Behavior, 11, 587-597.

Koziol-McLain, J., Coates, C. J., \& Lowenstein, S. R. (2001). Predictive validity of a screen for partner violence against women. American Journal of Preventative Medicine, 21, 93-100.

Kruger, D. J. (2003). Evolution and altruism: Combining psychological mediators with naturally selected tendencies. Evolution and Human Behavior, 24, 118-125.

Lalumière, M. L., Harris, G. T., Quinsey, V. L., \& Rice, M. E. (2005). The causes of rape: Understanding individual differences in male propensity for sexual aggression. Washington, DC: American Psychological Association.
McFarlane, J., Campbell, J. C., Wilt, S., Sachs, C. J., Ulrich, Y., \& Xu, X. (1999). Stalking and intimate partner femicide. Homicide Studies, 3, 300-316.

McKibbin, W. F., Goetz, A. T., Shackelford, T. K., Schipper, L. D., Starratt, V. G., \& Stewart-Williams, S. (2007). Why do men insult their intimate partners? Personality and Individual Differences, 43, 231-241.

McKinney, F., Cheng, K. M., \& Bruggers, D. J. (1984). Sperm competition in apparently monogamous birds. In R. L. Smith (Ed.), Sperm competition and evolution of animal mating systems (pp. 523-545). New York: Academic Press.

McKinney, F., Derrickson, S. R., \& Mineau, P. (1983). Forced copulation in waterfowl. Behavior, 86, 250-294.

McKinney, F., \& Stolen, P. (1982). Extra-pair-bond courtship and forced copulation among captive green-winged teal (Anas crecca carolinensis). Animal Behaviour, 30, 461-474.

McNulty, J. K., \& Hellmuth, J. C. (2008). Emotion regulation and intimate partner violence in newlyweds. Journal of Family Psychology, 22, $794-797$.

Meyer, S., Vivian, D., \& O’Leary, K. D. (1998). Men's sexual aggression in marriage: Couple's reports. Violence Against Women, 4, 415-435.

Nicolaidis, C., Curry, M. A., Ulrich, Y., Sharps, P., McFarlane, J., Campbell, D., . . \& \& Campbell, J. (2003). Could we have known? A qualitative analysis of data from women who survived an attempted homicide by an intimate partner. Journal of General Internal Medicine, 18, 788-794.

Painter, K., \& Farrington, D. P. (1999). Wife rape in Great Britain. In R. Muraskin (Ed.), Women and justice: Development of international policy (pp. 135-164). New York: Gordon \& Breach.

Parker, G. A. (1970). Sperm competition and its evolutionary consequences in the insects. Biological Reviews, 45, 525-567.

Paulozzi, L. J., Saltzman, L. E., Thompson, M. P., \& Holmgreen, P. (2001). Surveillance for homicide among intimate partners: United States, 19811998. MMWR, 50, SS-3.

Peters, J., Shackelford, T. K., \& Buss, D. M. (2002). Understanding domestic violence against women: Using evolutionary psychology to extend the feminist functional analysis. Violence and Victims, 17, 255264.

Pound, N. (2002). Male interest in visual cues of sperm competition risk. Evolution and Human Behavior, 23, 443-466.

Prentky, R. A., Knight, R. A., \& Sims-Knight, J. E. (1989). Developmental antecedents of sexual aggression. Development and Psychopathology, 1, 153-169.

Puente, S., \& Cohen, D. (2003). Jealousy and the meaning (or nonmeaning) of violence. Personality and Social Psychology Bulletin, 29, 449-460.

Riggs, D. S., \& O’Leary, K. D. (1989). A theoretical model of courtship aggression. In M. A. Pirog-Good \& J. E. Stets (Eds.), Violence in dating relationships: Emerging social issues (pp. 53-71). New York: Praeger.

Riggs, D. S., \& O'Leary, K. D. (1996). Aggression between heterosexual dating partners: An examination of a causal model of courtship aggression. Journal of Interpersonal Violence, 11, 519-540.

Russell, D. E. H. (1982). Rape in marriage. New York: Macmillan.

Schmitt, D. P., \& Buss, D. M. (1996). Strategic self-promotion and competitor derogation: Sex and context effects on the perceived effectiveness of mate attraction tactics. Journal of Personality and Social Psychology, 70, 1185-1204.

Schmitt, D. P., \& Buss, D. M. (2001). Human mate poaching: Tactics and temptations for infiltrating existing mateships. Journal of Personality and Social Psychology, 80, 894-917.

Schützwohl, A. (2005). Sex differences in jealousy: The processing of cues to infidelity. Evolution and Human Behavior, 26, 288-299.

Schützwohl, A. (2008). The disengagement of attentive resources from task-irrelevant cues to sexual and emotional infidelity. Personality and Individual Differences, 44, 633-644. 
Seymour, N. R., \& Titman, R. D. (1979). Behaviour of unpaired male black ducks (Anas rupribes) during the breeding season in a Nova Scotia tidal marsh. Canadian Journal of Zoology, 57, 2412-2428.

Shackelford, T. K., \& Buss, D. M. (1997). Cues to infidelity. Personality and Social Psychology Bulletin, 23, 1034-1045.

Shackelford, T. K., Buss, D. M., \& Peters, J. (2000). Wife killing: Risk to women as a function of age. Violence and Victims, 15, 273-282.

Shackelford, T. K., \& Goetz, A. T. (2004). Men's sexual coercion in intimate relationships: Development and initial validation of the Sexual Coercion in Intimate Relationships Scale. Violence and Victims, 19, 541-556.

Shackelford, T. K., \& Goetz, A. T. (2007). Adaptation to sperm competition in humans. Current Directions in Psychological Science, 16, 47-50.

Shackelford, T. K., Goetz, A. T., Buss, D. M., Euler, H. A., \& Hoier, S. (2005). When we hurt the ones we love: Predicting violence against women from men's mate retention tactics. Personal Relationships, 12, $447-463$.

Shackelford, T. K., Goetz, A. T., McKibbin, W. F., \& Starratt, V. G. (2007). Absence makes the adaptations grow fonder: Proportion of time apart from partner, male sexual psychology, and sperm competition in humans (Homo sapiens). Journal of Comparative Psychology, 121, 214-220.

Shackelford, T. K., LeBlanc, G. J., \& Drass, E. (2000). Emotional reactions to infidelity. Cognition \& Emotion, 14, 643-659.

Shackelford, T. K., LeBlanc, G. J., Weekes-Shackelford, V. A., BleskeRechek, A. L., Euler, H. A., \& Hoier, S. (2002). Psychological adaptation to human sperm competition. Evolution and Human Behavior, 23, 123-138.

Shackelford, T. K., \& Pound, N. (Eds.). (2006). Sperm competition in humans. New York: Springer.

Shackelford, T. K., Pound, N., \& Goetz, A. T. (2005). Psychological and physiological adaptations to sperm competition in humans. Review of General Psychology, 9, 228-248.

Shackelford, T. K., Schmitt, D. P., \& Buss, D. M. (2005). Universal dimensions of human mate preference. Personality and Individual Differences, 39, 447-458.

Smith, R. L. (1984). Human sperm competition. In R. L. Smith (Ed.), Sperm competition and the evolution of animal mating systems (pp. 601-660). New York: Academic Press.

Starratt, V. G., Goetz, A. T., Shackelford, T. K., \& Stewart-Williams, S. (2008). Men's partner-directed insults and sexual coercion in intimate relationships. Journal of Family Violence, 23, 315-323.

Starratt, V. G., Shackelford, T. K., Goetz, A. T., \& McKibbin, W. F. (2007). Male mate retention behaviors vary with risk of female infidelity and sperm competition. Acta Psychologica Sinica, 39, 523-527.

Stewart-Williams, S. (2008). Human beings as evolved nepotists: Exceptions to the rule and effects of cost of help. Human Nature, 19, 414-425.
Stuart, G. L., \& Holtzworth-Munroe, A. (2005). Testing a theoretical model of the relationship between impulsivity, mediating variables, and husband violence. Journal of Family Violence, 20, 291-303.

Symons, D. (1979). The evolution of human sexuality. New York: Oxford University Press.

Thomson, J. W., Patel, S., Platek, S. M., \& Shackelford, T. K. (2007). Sex differences in implicit association and attentional demands for information about infidelity. Evolutionary Psychology, 5, 569-583.

Thornhill, R., \& Thornhill, N. W. (1992). The evolutionary psychology of men's coercive sexuality. Behavioral and Brain Sciences, 15, 363-421.

Trivers, R. L. (1972). Parental investment and sexual selection. In B. Campbell (Ed.), Sexual selection and the descent of man 1871-1971 (pp. 136-179). Chicago: Aldine.

U.S. Department of Justice. (1998). Violence by intimates: Analysis of data on crimes by current or former spouses, boyfriends, and girlfriends. Washington, DC: Author.

Valera, F., Hoi, H., \& Kristin, A. (2003). Male shrikes punish unfaithful females. Behavioral Ecology, 14, 403-408.

Walker, L. E. (1979). The battered woman. New York: Harper \& Row.

Watts, C., Keogh, E., Ndlovu, M., \& Kwaramba, R. (1998). Withholding of sex and forced sex: Dimensions of violence against Zimbabwean women. Reproductive Health Matters, 6, 57-65.

White, J. W., McMullin, D., Swartout, K., Sechrist, S., \& Gollehon, A. (2008). Violence in intimate relationships: A conceptual and empirical examination of sexual and physical aggression. Children and Youth Services Review, 30, 338-351.

Wilkinson, D. L., \& Hamerschlag, S. J. (2005). Situational determinants in intimate partner violence. Aggression and Violent Behavior, 10, 333361

Wilson, M., \& Daly, M. (1992). The man who mistook his wife for a chattel. In J. H. Barkow, L. Cosmides, \& J. Tooby (Eds.), The adapted mind (pp. 289-322). New York: Oxford University Press.

Wilson, M., \& Daly, M. (1993). An evolutionary psychological perspective on male sexual proprietariness and violence against wives. Violence and Victims, 8, 271-294.

Wilson, M., \& Daly, M. (1998). Lethal and nonlethal violence against wives and the evolutionary psychology of male sexual proprietariness. In R. E. Dobash \& R. P. Dobash (Eds.), Rethinking violence against women (pp. 199-230). Thousand Oaks, CA: Sage.

Wilson, M., Daly, M., \& Daniele, A. (1995). Familicide: The killing of spouse and children. Aggressive Behavior, 21, 275-291.

Wyckoff, G. J., Wang, W., \& Wu, C. (2000). Rapid evolution of male reproductive genes in the descent of man. Nature, 403, 304-308.

Received June 23, 2009

Revision received July 28, 2009

Accepted July 31, 2009 